\title{
Accounting for uncontrollable factors in executive incentive scheme designs
}

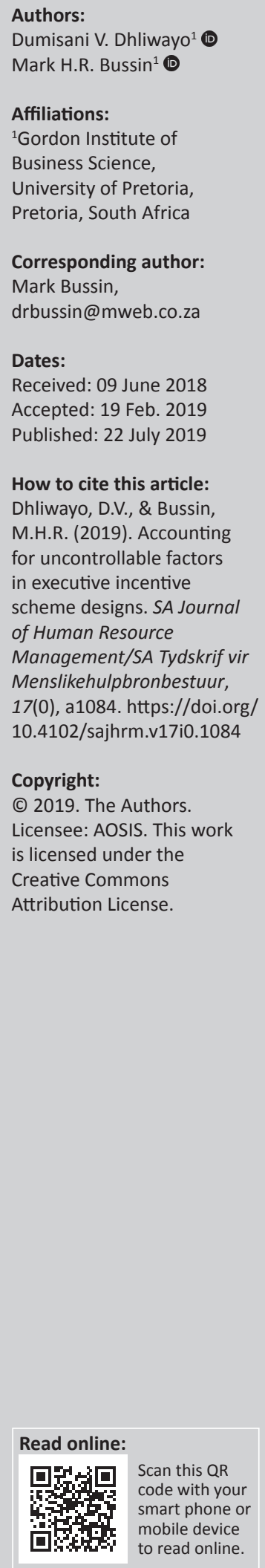

Orientation: Classic agency theory posits that the impact of uncontrollable factors should be excluded from executive remuneration. Existing research, however, shows a departure from this theory.

Research purpose: This study sought to determine the approaches organisations take and the reasons thereof to account for uncontrollable factors in the design of their executive incentive schemes.

Motivation for the study: There is little research in South Africa on how organisations account for uncontrollable factors in the design of their incentive schemes.

Research approach/design and method: An exploratory qualitative research using semistructured interviews was conducted.

Main findings: South African organisations are not strictly conforming to the classic agency theory prediction for uncontrollable factors as some allow the impact of uncontrollable factors to be included, and further, hybrid approaches may be applied.

Practical/managerial implications: The menu of approaches presented will aid designers of incentive schemes to identify a tried and tested approach to adopt or improve their incentiverelated policies.

Contribution/value-add: An expanded list of uncontrollable factors identified from South Africa's uniqueness is presented. Models for (1) accounting for uncontrollable factors in incentive schemes and (2) pay for individual performance versus firm performance dilemma are presented. These add to the body of existing literature.

Keywords: executive incentive schemes; remuneration; compensation; pay-for-luck; uncontrollable factors.

\section{Introduction}

\section{Orientation}

Executive remuneration is a burning issue with questions abounding around its fairness and, in some parts of the world, attempts to regulate its determination and disclosure issues (Chiu, Oxelheim, Wihlborg, \& Zhang, 2016). For purposes of this research, executive means executive management-being the highest decision-making authority in the organisation after the governing body (Institute of Directors in Southern Africa, 2016). The variable element of executive remuneration is in many cases linked to corporate earnings, yet these earnings are affected by many factors that may be viewed as being outside the actions or control of executives. The terms 'pay-for-luck' and 'luck' have been coined as synonyms for uncontrollable factors and have been used by a number of researchers (Brookman \& Thistle, 2013; Campbell \& Thompson, 2015; Chiu et al., 2016; Jiménez-Angueira \& Stuart, 2013; Jouber \& Fakhfakh, 2012; Mollerstrom, Reme, \& Sørensen, 2015).

In a South African context, shareholder activism around executive remuneration has been well documented. Consider 2015, for example, when certain shareholders of Capitec Bank voted against the bank's remuneration policy, citing their discontent with incentives that did not reflect the performance of executives (Crotty, 2015).

From another perspective, South Africa grapples with inequality, which is measured on different scales. In Bloomberg's Global Chief Executive Officer (CEO) Pay-to-Average Income Ratio, South Africa ranks worst, with CEOs earning on average 541 times more than the average worker (Lu \& Melin, 2016). 
In the United States, Deloitte's Chief Financial Officer Insights Survey posed the question, 'Should forex swings affect incentive remuneration?' This was after a shock strengthening of the US dollar caused major variations in corporate earnings. The results of the survey showed that $70 \%$ of chief financial officers (CFOs) identified the issue as being relevant for their companies, while over $75 \%$ of these CFOs did not plan to adjust their executive incentive schemes, arguing that the fates of the executives and shareholders should be parallel (Deloitte, 2015).

Various attempts are being made to either guide or legislate the fairness of executive remuneration. In South Africa, the now-retired King III Report stated in Section 148 that in determining executive remuneration, uncontrollable factors affecting firm performance should only be considered to a limited extent (Institute of Directors in Southern Africa, 2009). The current King IV Report on Corporate Governance in South Africa is less explicit, recommending the reporting of performance measures and targets used to determine variable executive remuneration, adding that executive remuneration should be fair and responsible (Institute of Directors in Southern Africa, 2016). In the United States, the Securities and Exchange Commission (SEC) issued a proposed rule entitled 'Pay versus performance', which seeks to improve shareholders' ability to objectively assess the relationship between executive remuneration and corporate earnings (Securities and Exchange Commission, 2015).

\section{Research purpose and objectives}

This study was motivated by the need to understand the issues that principals and agents of organisations in South Africa face, in as far as deciding how to account for the impact of uncontrollable factors in the design of their executive incentive schemes. Some proponents argue for the explicit exclusion of gains from uncontrollable factors in the design of variable executive remuneration (Bebchuk \& Fried, 2006; Institute of Directors in Southern Africa, 2017). The study is undertaken in the context of a prevailing environment of intense scrutiny of executive remuneration. By drawing on the views of key players in the remuneration policy-setting structures of a diverse range of organisations, this study aimed to determine the approaches organisations take and the reasons thereof to account for uncontrollable factors in the design of their executive incentive schemes. The collation of this information will assist designers and decision-makers of incentive schemes in the crafting of better rules.

\section{Literature review}

\section{Agency theory and its challenges}

The setting of executive remuneration is anchored in the agency theory, which is concerned with the delegation relationship between one party as the principal and another party as the agent. According to Eisenhardt (1989), in this relationship, two problems occur: (1) a conflict of goals between the principal and the agent and (2) the difficulty or economic feasibility of the principal validating what the agent is actually doing. In the context of this study, uncontrollable factors may be viewed differently, while establishing responsibility for such factors may prove to be difficult.

According to Bebchuk, Fried and Walker (2002), the optimal executive contract has to consider the attraction and retention of talent present in an agent, incentivise the agent to align to the interests of the principal and minimise residual loss - the cost to the principal caused by the abnormal activities of the agent. Sun and Shin (2014) state that the setting of executive remuneration involves the belief of board members that the activities of executives reflect corporate outcomes. The implication is, therefore, that the remuneration awarded to executive management will reflect the reward for those actions that the agent has deliberately taken and, by extrapolation, exclude the impact of uncontrollable factors (Jouber \& Fakhfakh, 2012).

Other theories exist that also attempt to explain the relationship between principals and agents. Freeman's stakeholder theory (Freeman, 1984), for example, looks beyond the traditional shareholder and manager relationship, recognising other stakeholders such as the broader classification of employees, governments, political groups and more. The theory also posits that various stakeholders use the organisation to accomplish numerous, and not always common, interest objectives (Donaldson \& Preston, 1995). The agency theory is applied in this research because of its narrower and more intimate focus on the specific relationship between principals and agents and, in the current context, with the principal as the expected chief regulator of executive remuneration.

\section{Pay for performance or luck?}

Cărăușu (2015) posited that remuneration schemes enable shareholders to ensure that the quantum of benefits awarded to managers is entwined with the organisation's performance. Bebchuk and Fried (2006) argue that the arm's length assumption that exists in the pay-setting process has in fact strayed, particularly so in publicly traded organisations where managerial power actively shapes pay arrangements for managers.

Numerous quantitative studies have investigated whether or not there is a correlation between executive remuneration and firm performance (Bertrand \& Mullainathan, 2001; Chiu et al., 2016; Feriozzi, 2011; Garvey \& Milbourn, 2006). The direction of attention is illustrated by the recommendation of the US SEC, that is, that registrants disclose in a clear manner 'the relationship between executive remuneration actually paid and the financial performance of the registrant' (Securities and Exchange Commission, 2015, p. 1).

In Europe, recent regulations issued by the supervisory authorities aim to 'fortify the correlation between the 
incentive pay and the organisation's performance so that each manager can really contribute to the bank value creation, especially from a long-term perspective' ( $D^{\prime}$ Apolito \& Iannuzzi, 2017, p. 169). It would thus seem that both in the United States and Europe, there is pressure for a correlation between executive remuneration and reported financial performance. If this is indeed the case, the pressure to align pay to company performance when there is an uncontrollable negative factor means that the performance input of an executive could be overshadowed with negative consequences such as demotivation.

Paulo and Le Roux (2016) formulated the Paulo-Le Roux Index that attempts to show the relationship between executive remuneration and the value added to the firm by the executive. The index is quantitative, drawing on audited financials of a firm implying uncontrollable factors are treated as endogenous. Hölmstrom (1982) advocates for the exclusion of uncontrollable factors in the optimal remuneration contract. But what exactly is the process to determine whether a factor is exogenous or endogenous? Researchers such as Ford (1985) suggest that this process is informed by psychological factors. Sun and Shin (2014) introduce contextual factors to the process, arguing that the external environment influences the extent to which a decision-maker of executive remuneration would attribute cause to. By way of example, Sun and Shin (2014) postulate that principals may be concerned with the adverse impact of exogenous events on executives' incentives leading to the risk of their departure. Considering the findings of Sun and Shin (2014), specifically the granting of a greater number of stock options to CEOs during a recession, it appears, therefore, that a battle of principle versus reality exists, which policymakers have to seek a delicate balance.

\section{Shareholder activism and income inequality}

In a study on the history of shareholder activism in the United States, Gillan and Starks (2007) found a marked increase in executive remuneration proposals for the years 2001 to 2005 against the years 1987 to 1994 . According to Greve (2014), South Africa has followed global trends propelled by a large international shareholder base in the country.

In Bloomberg's report on Global CEO Pay-to-Average Income Ratio, South Africa ranked worst, with CEOs earning on average 541 times more than the average worker (Lu \& Melin, 2016). Given the growing concerns about executive remuneration and assuming that executives are indeed rewarded for favourable uncontrollable factors, and the same being deemed unacceptable by shareholders and society in general, a rise in shareholder activism with respect to executive remuneration would be expected. It is therefore clear that executive remuneration is in the spotlight, and thus by implication, so are its drivers, which include the impact of uncontrollable factors.

\section{The concept of fairness}

According to Bol (2008), the traditional agency model has not recognised the importance of perceived fairness in remuneration contracting. Employees seek distributive fairness - associated with the quantum of the remuneration, and procedural fairness - associated with the process used to arrive at the quantum of the remuneration. Perceived unfairness breeds negative attitudes, which in turn leads to reduced motivation and possibly even negative actions by employees against the organisation.

The Remuneration Committee Forum, as an arm of the Institute of Directors of Southern Africa, notes that discussions on fair and responsible pay can be expected to yield differing views 'as they depend on who the debate is held with' (Institute of Directors in Southern Africa, 2017, p. 1). The Forum's guidance on fair executive remuneration is seen to be a bias towards high incentives alone, discouraging a number of practices. The facts on the ground are however different. Bertrand and Mullainathan (2001) in their research found that CEOs were rewarded for positive gains from uncontrollable factors. In addition, Bertrand and Mullainathan (2001) found that this practice was stronger among poorly governed organisations, and this is also confirmed by the research of Brookman and Thistle (2013); Feriozzi (2011); Francis, Hasan, John and Sharma (2013); and Garvey and Milbourn (2006). In a related South African context, Bussin and Modau (2015) found a decline in the relationship between executive remuneration and the financial performance of a firm citing a move to nonperformance measures which may speak of better governance. However, in South African state-owned entities (SOEs), Bussin and Ncube (2017) found a strong link between CEO and CFO pay to the financial performance of the SOE. Subsequent research by Bezuidenhout, Bussin, and Coetzee (2018) on Schedule 2 State-Owned Enterprises in South Africa found a strong positive correlation between total CEO remuneration and operating profit, and a negative correlation between total CEO remuneration and net profit.

In a test of fairness posed to CFOs, Deloitte (2015) researched the approaches organisations in the United States were following in response to the shock movement in the US dollar exchange rate. Deloitte identified three schools of thought being:

- Do nothing - arguing for the fate of executives to be tied to those of shareholders. When the tide is high everybody gains, and when it is down everybody loses.

- Hold-harmless approach - arguing for the exclusion of gains and losses from uncontrollable factors.

- Corridor approach - arguing for proportional accountability to management for some of the gains and losses from uncontrollable factors.

The results of the survey showed that $75 \%$ of affected CFOs did not plan to adjust their executive incentive schemes, arguing that the fates of the executives and shareholders should be parallel (Deloitte, 2015). 
In attempting to explain the strong correlation between executive remuneration and gains from uncontrollable factors, researches have suggested that skimming, where a CEO gains control of the pay-setting process itself, was a likely cause for the observation (Bertrand \& Mullainathan, 2001; Garvey \& Milbourn, 2006). Taking this view, it may be logically extrapolated that despite the negative impact of the stronger US dollar on executive incentive schemes, this was an odd occurrence where the uncontrollable factors negatively affected executive remuneration. For CFOs to argue for intervention would in effect establish a principle, the 'HoldHarmless approach', whereby gains from uncontrollable events, which appear to be the norm, would be excluded from incentives to the detriment of executives. In the greater scheme of things, 'one bad year' would be a small price to pay to ensure that skimming remains embedded in the pay-setting process of the organisation. The cumulative studies to date point to the existence of complexity in as far as fairness is concerned, and therefore, the issue is worthy of further research.

\section{The role of corporate governance in executive remuneration}

Cărăuşu (2015) asserted that through the use of policies, corporate governance serves as a mechanism to control, supervise and counsel an organisation, and ensures boundaries in the relations between principals and agents.

A number of researchers found that good corporate governance mitigated the instances of executive remuneration being affected by benefits of uncontrollable factors (Bertrand \& Mullainathan, 2001; Jiménez-Angueira \& Stuart, 2013; Jouber \& Fakhfakh, 2012).

Bebchuk and Fried (2004) advocated for 'shareholder approval of executive remuneration plans that include features identified as "suspect" by those designing the arrangements'. It is, therefore, possible that principals could approve the award of executive remuneration that has been enhanced by the impact of uncontrollable factors if they deem the surrounding circumstances to be acceptable. The essence of the recommendation is thus that the decision is taken after full disclosure to the principals of the organisation.

\section{In summary}

It is evident that there are a range of views and justifications regarding how designers of executive incentive schemes ought to account for the impact of uncontrollable factors, each with their own repercussions, presenting agents and principals with rigorous analysis and choices to make in light of growing shareholder activism and income inequality concerns.

\section{Research design Research approach}

This study applied the qualitative approach utilising in-depth, semi-structured interviews. Qualitative research explores and seeks to understand the meaning that a person or a group of people ascribe to a social or human problem (Creswell, 2009). The subject of this research is associated with subjective matters of fairness and governance. Questions of a 'what' nature were core to the research, that is, 'What is the nature of the uncontrollable factors that businesses are confronted with?' and 'What interventions are in place to account for the impact of uncontrollable factors in the design of executive incentive schemes?'

In-depth interviews are useful when a researcher seeks to establish a deeper understanding of a respondent's thoughts and behaviours (Boyce \& Neale, 2006). The interviews gathered the views of participants at a set time, despite the fact that these views may have been formed over a period. A cross-sectional research was thus conducted.

\section{Research strategy}

An interpretivist theoretical approach was adopted in the study. According to Blaikie (2011):

The study of social phenomena requires an understanding of the social worlds that people inhabit, which they have already interpreted by the meanings they produce and reproduce as a necessary part of their everyday activities together. (p. 509)

Creswell (2009) stated that the experiences of individuals lead to them developing subjective meanings of those occurrences. The way in which companies deal with the impact of uncontrollable factors reflects the collective opinion of individuals who have applied their minds to the various issues at hand. Interpretivism is therefore aligned to the understanding that was sought through this research.

\section{Research method}

\section{Research setting}

The research was conducted in South Africa, drawing on corporate entities from a diverse range of industries represented in the South African economy such as mining, agriculture, insurance, retail, information technology and fast food. With many entities drawing on the services of external subject matter experts, leading practitioners in the remuneration consulting arena were also included.

\section{Entrée and establishing researcher roles}

The research sought to interview individuals who influence the formulation of executive remuneration policy such as non-executive directors, executive directors, other senior executives and remuneration practitioners in the South African corporate environment. This was achieved by using key contacts of a leading South African remuneration practitioner. Interviews were requested through emails and follow-up telephone calls, some of which were initially through gatekeepers in the form of personal assistants to the interviewees. 


\section{Research participants and sampling methods}

The research sought the participation of key actors in the remuneration arena who have significant influence. These included Remuneration Committee (RemCo) members and remuneration consultants. Purposive non-probability sampling was utilised for this research. According to Saunders and Lewis (2012), when a researcher selects a purposive sample, judgement is used to actively choose those who will be best able to answer the research question and meet the objectives. Fourteen representative participants, with a data saturation over-rider, were selected on the basis of diversity of the industries representing the South African economy to make up the sample. This covered mining, petrochemicals, pulp and paper manufacturing, banking, retail, and professional services to name a few. Also, the inherent uncontrollable factors associated with some of these businesses, for example, commodity prices for mining, interest rates for banks and exchange rates generally across all sectors, were also considered. According to Morgan (2012), in the majority of qualitative studies, the research goals accentuate an intimate understanding of a particular matter, and such goals are best attained through small sample sizes.

\section{Data collection methods}

In the main, in-depth, face-to-face interviews were utilised as the primary data collection mechanism for this study. One interview was conducted by video conference, while five interviews were conducted by telephone. In-depth interviews encourage participants to explore in detail the subject under investigation in their own words (Cook, 2012). According to Cook (2012), the in-depth interview is one of the most applied methods of data collection in qualitative research.

\section{Strategies employed to ensure data quality and integrity}

According to Lincoln (2004), 'trustworthiness criteria provide yardsticks by which the rigor, validity, systematic nature of methods employed, and findings of qualitative studies may be judged' (p. 1145). The criteria for trust were addressed as follows in this research:

Credibility aims to show that the research was conducted accurately through the use of processes. The research describes the research setting, the population, the sample and theoretical framework in detail to ensure its integrity.

Replicability aims for consistency between researchers thereby placing more faith in the truth of the research findings (Seale, 2004). The sample was made up of executives and remuneration consultants. This means that the study could be replicated in other companies across the country.

Transferability implies that the research results can be transferred to other contexts and situations beyond the scope of the study context (Jensen, 2008b). A full picture of the context of the research, the research design and the respondents has been painted. This study could be undertaken in any country.
Dependability recognises that the research context is not static and a researcher may be confronted with situation quite different from what was expected (Jensen, 2008a). The data collection process has been well documented, with preserved evidence in the form of audio recordings and professionally transcribed scripts.

\section{Data analysis}

Pope, Ziebland and Mays (2000) state that 'qualitative research uses analytical categories to describe and explain social phenomena' (p. 114). These categories can be established gradually from the data (inductively), or used at the onset or some later stage during the analysis (deductively), as a way of tackling the data (Pope et al., 2000). In summary, the data collected during the research were analysed both deductively, with reference to the known, and inductively, for what was yet to be established. This was accomplished by arranging the interview outputs into similar emerging themes.

\section{Ethical considerations}

Ethical clearance was granted by the Gordon Institute of Business Science and participants were given the option not to participate as it was voluntary and anonymous.

\section{Results}

This research was conducted with the aim of determining the approaches organisations take and the reasons thereof to account for uncontrollable factors in the design of their executive incentive schemes. The results are discussed under three broad headings.

\section{The nature of uncontrollable factors faced by organisations}

Respondents were asked to identify the critical uncontrollable factors affecting their businesses, and in the case of the remuneration consultants, those that were common among their consulting clients. Through a process of coding of the concepts identified in the transcribed interviews, the research identified 10 factors as presented in Figure 1. These factors are discussed below.

Macroeconomic factors: The most quoted factor was exchange rate fluctuations affecting either direct trade transactions or foreign-based operations. Inflation did not feature as a major uncontrollable factor for the respondents in the interview sample. Given the focus on inflation through inflation targeting by the South African monetary authorities, as well as the fact that South African inflation has been within the targeted parameters, businesses were unlikely to identify inflation as a major uncontrollable factor they were faced with either historically or recently.

Political factors: In many instances, the originating political event is seen manifesting itself in one or more uncontrollable 


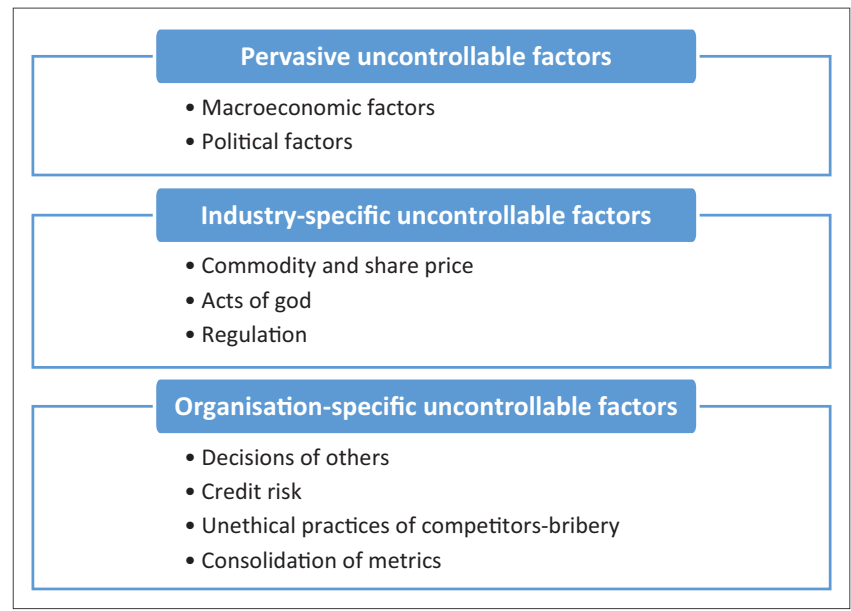

FIGURE 1: The nature of uncontrollable factors confronting South African companies.

factors. The memory of the impact of political events in the latter years of the Zuma presidency in South Africa was cited by some respondents.

Commodity and share price: The price of commodities and the price of shares were recurrent factors, the former being inherent to the associated industry and the latter experienced in organisations where share linked incentives are present.

Acts of God: Some industries such as mining and agriculture were prone to physical or natural events beyond the influence of man. Earth tremors affecting mining operations as well as the impact of drought on agricultural activities were cited.

Regulation: In developed economies and markets, regulation is seen as being uncontrollable in the context of the associated costs.

Decisions of others: This factor relates to the decisions of past decision-makers having an impact on the current incentive schemes. Two respondents in the sample cited the impact of past debt decisions having a prolonged negative impact on the profitability of their organisations.

Credit risk: In a liability-based asset management business, the credit risk of instruments in their portfolio was cited as an uncontrollable factor in the context of the financial solutions offered by the business.

Unethical practices of competitors - bribery: A respondent in the highly competitive information technology industry cited the impact of competitors paying bribes to secure business to the disadvantage of the respondent's ethical company.

Consolidation of metrics: Some executives felt that the consolidation of metrics for different operations curtailed their incentives. It is not inconceivable to imagine that the dilution of a profitable operation in one country by a poorly performing operation in another country would be viewed as uncontrollable for the executive in the former operation. It is also unlikely that the agent in a poorly performing operation would complain about his or her incentive benefiting from another well-performing operation.

\section{Concerns regarding the fairness of uncontrollable factors}

Respondents in the research were asked if they had any concerns regarding the fairness, from any quarter, about the exclusion or inclusion of gains or losses from uncontrollable factors in incentive scheme pools.

Executives are incentivised to make the most of the conditions. In an environment of zero-based targets, often the principal is concerned about management setting conservative targets, so that the actual results reflect a greater stretch against the target and hence conducive for higher incentives. This setting may therefore have a bearing on how the effects of uncontrollable factors are dealt with when incentives are determined.

A variety of concerns were expressed by the respondents, a few of which are included under the following subheadings. Surprisingly, despite the sample being skewed towards executives, the majority of concerns raised were in the camp of the principal. The concerns were categorised into four broad themes as depicted in Figure 2.

Pay for performance concern: This concern is linked to the question, 'are executives being rewarded for performance'? While uncontrollable factors and their impacts are acknowledged, respondents submitted that executives can make specific decisions that either mitigate the uncontrollable unfolding event or sometimes even allow for the maximisation of returns. Respondent 7 expressed this assertion as follows:

'So, I am saying that for me, when you look at uncontrollable factors, they are not totally uncontrollable. Maybe you can't control the factor, but you can plan for it. But not only in your budgeting, and, but in your strategy of the business ... if you have a strategy in place, a business strategy, to cope with the socalled uncontrollable factors, then if you link variable pay to that, you will be in a much better position.' (Respondent 7, CEO remuneration consulting)

The executive looks ahead and plans deliberate actions based on the predicted business environment. The uncontrollable factor is therefore not seen in isolation, but rather in a context.

A hypothetical probing question was presented using an example of a tomato farm manager employed by the respondent. The farm manager grows and delivers product to the market at the ruling price. The question was crafted to create distance from the day-to-day experiences of the respondents, thus seeking out their philosophical position regarding uncontrollable factors. In the example, on day one, the ruling market price for tomatoes is R20.00 per kilogram, and the next day, it is R100.00 per kilogram. The question sought to establish how the respondent, as principal, would 


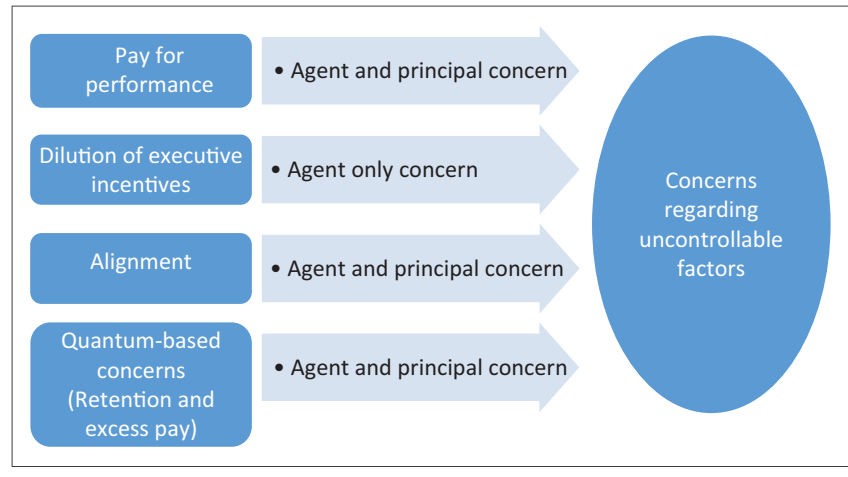

FIGURE 2: Categories of concerns regarding uncontrollable factors.

calculate the incentive to be awarded to the farm manager given the uncontrollable price gain.

The more critical respondents expressed a view that for any uncontrollable factor, a thorough assessment must be made of that factor to establish whether the agent could have done something to respond to the factor. For instance, the farmer has the option to effect cost efficiency improvements or to schedule the delivery of the product to the market for best return. A more brutal view captured by Respondent 10, a CEO for an executive search agency, was 'But everybody lives and dies by the end results', and therefore, performance is ultimately measured by the financial results.

Some respondents highlighted the linkage of critical assessments to the existence and quality of an experienced RemCo. These respondents reported that the lack of a knowledgeable and experienced RemCo usually resulted in greater concerns by principals and vice versa. Respondent 2 commented:

'I find that management often tries to argue that they were uncontrollable factors, but then they need careful scrutiny because managers for obvious reasons try to argue their own case ... I think therein lies a safeguard that I am not convinced that all companies have. My experience with some of the companies that I have been consulting to is that the members of the remuneration committee are, not in my opinion, sufficiently knowledgeable about these matters, they are not sufficiently informed on remuneration trends, you know, guidelines from King and a whole lot of other things, and I am not sure if they would apply the same degree of scrutiny. So, then I expect that the shareholders would feel a lot more concerned.' (Respondent 2 , human resources executive, mining)

Dilution of executive incentives: This concern referred to the inclusion or exclusion of uncontrollable factors that would result in reduced incentive pay and was expressed from the viewpoint of the agent. It was however observed that the reaction by agents to these dilutive concerns effectively became an associated concern for the principals as they cited the risk of executives exiting because of dissatisfaction with their incentives. In support of this, Respondent 7 remarked:

'The executives get grumpy, they get quite mobile, they can go to other companies, and companies say, oh, we better revisit our

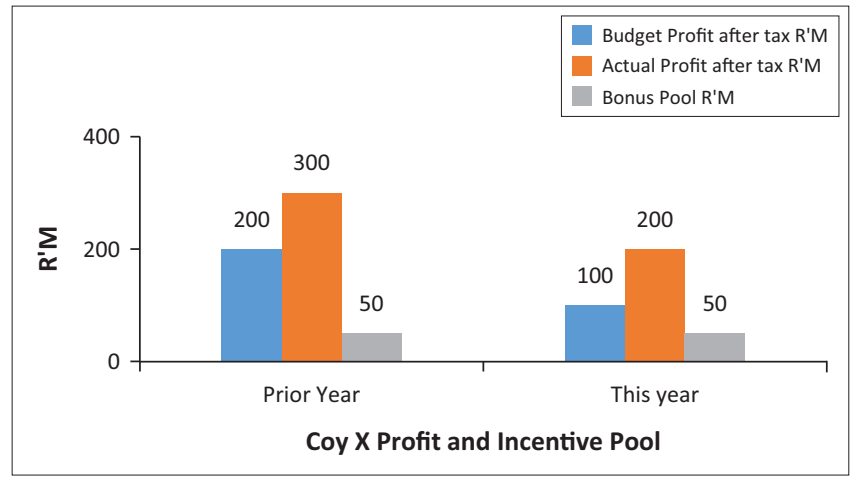

$\mathrm{R}^{\prime} \mathrm{M}$, rand million.

FIGURE 3: Illustration of the lack of alignment.

schemes, and the only thing they can do is look at the targets.' (Respondent 7, CEO, remuneration consulting)

Alignment concern: This largely principal-based concern relates to the perceived lack of alignment between what shareholders earn versus what executives earn. The examples cited were very much industry-specific and also spoke to the basis on which incentive targets were set, that is, either budget-based or growth-based. Figure 3 succinctly illustrates the concern.

In the depiction above, where the bonus pool has been calculated as $50 \%$ of the stretch results, that is, actual profitability less budgeted profitability, the bonus pool is the same for both years at R50 million but funded from R300m profit in the prior year versus $\mathrm{R} 200 \mathrm{~m}$ profit in the current year. The principal would note a lack of alignment in that actual profits were lower by $\mathrm{R} 100 \mathrm{~m}$, but the bonus pool stayed the same.

Respondent 6 recalled a year where the actual profit marginally missed the target, in part, because of the existence of uncontrollable factors. The actual profit was the organisation's second highest recorded profit. Consequently, the rules of the incentive scheme dictated that no incentives would be paid. The CEO felt that he would be hard-pressed to tell his executive team and other employees that in the year of the second highest profit, there would be no incentive payments, while the shareholders would be rewarded handsomely.

Quantum-based concerns: All the activities and policies around executive remuneration culminate in a determined quantum to be paid to executives. This quantum enters the judgement courts of various stakeholders. These stakeholders consider the quantum in light of all the known factors, but may not be in a position to specifically break down the contribution of each factor. Uncontrollable factors, therefore, contribute to either high or low pay, and consequential concerns around the quantum of payment arise. In this research, the concerns were related to the retention of key executives on the lower end of the incentive quantum scale and to the excessive remuneration of executives at the top 


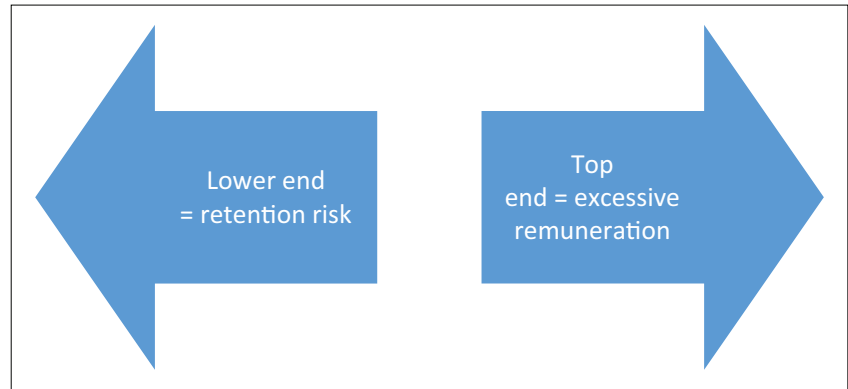

FIGURE 4: Quantum-based concerns on the incentive pay scale.

end of the incentive quantum scale. These concerns are illustrated in Figure 4.

Because of consecutive lower incentive payments that may have been affected by uncontrollable factors, and because of peer incentives, executives may opt to seek alternative employment where they believe they will experience a more favourable environment than their present. Respondent 5, a human resources executive, in the petrochemicals industry, stated, 'It's starting to become a concern', when referring to increasing staff turnover, which she believed was linked to a protracted period of 'suboptimal' bonuses. In contrast, Respondent 4, with a dual role as principal and agent, remarked that he would be happy to see the exit of anyone in his organisation who left because of the negative impact of uncontrollable factors, expecting that agents should be committed through the highs and the lows.

On the higher end of the incentive scale was expressed the concern captured in the term, 'the unspoken rule', which describes the preference of shareholders to see executive remuneration moderated downwards but never upwards. Respondent 1, a human resources executive, in the banking industry, remarked '... and discretion should normally only be applied downwards and not upwards. That's a bit of an unwritten rule, but institutional shareholders like it'.

Over and above the 'unspoken rule', the social challenges of South Africa's high-income inequality are also viewed to be part fuelled by the impact of favourable uncontrollable factors.

\section{Approaches adopted by organisations for uncontrollable factors}

Given the nature of uncontrollable factors and the concerns around them as expressed from the viewpoint of various stakeholders, the leading question sought to establish how then organisations design their schemes to accommodate the uncontrollable factor environment. Broadly, companies were found to practice interventions at two possible levels, either primary approaches or secondary approaches.

\section{Primary uncontrollable factor approaches}

These consider the nature of the uncontrollable factor and its associated characteristics, for example, its volatility, as well as some aspects of the organisational environment such as the target-setting philosophy. Drawing on Deloitte's survey, the approaches adopted may be classified into four types:

Hands-off approach leaves things as they are without any intervention. The approach was favoured by environments that were non-volatile and, secondly, where a strong alignment culture existed. An alignment culture in the context of this research refers to an organisation where the fates of shareholders and executives are accepted to be the same.

The agricultural sector is subject to events such as drought which can have severe consequences, yet the occurrences of droughts are infrequent, which makes them the exception rather than the norm, and as such, one organisation in the sample did not adjust incentives for the negative impact of drought.

Corridor approach allows for some of the impact of uncontrollable factors to flow through to incentive schemes. This approach attempts to regulate, within a pre-defined range, the negative or positive impact of uncontrollable factors. The approach is conducive for environments that are characterised by the following:

- Zero-based targets: These consider the specific circumstances for the coming period, which may have no relationship to the prior period. One respondent stated that in his organisation, management tended to set conservative targets. Consequently, the RemCo in that organisation imposed a price cap of $10 \%$ of the budgeted revenue price, either way.

- Short-term incentive schemes (STIs): Most long-term incentive (LTI) schemes mentioned by respondents were share-based. Intrinsically, it is difficult to unwind the impact of uncontrollable factors from the value of a share, as that share value is the sum total of those factors and many others. In the long-term, uncontrollable factors tend to inform business cycles, which are inherently important to the value of the business. Thus, it appears not to be common practice to try and unwind, whether in whole or part, the impact of uncontrollable factors in LTI schemes, but conducive for STIs.

- Volatile factors or environment: When zero-based budgets were discussed, the underlying issue raised was the intent of management to set conservative budgets. However, zero-based budgets can be informed by factors subject to volatility, and the RemCo of the organisation may deem it necessary to restrict the upswings or downswings. Again, the $10 \%$ price cap and floor mentioned above demonstrate the environment that appears to support the Corridor approach.

Unwinding approach completely removes the impact of uncontrollable factors. The unwinding approach is an overextension of the Corridor approach in that, instead of unwinding a portion of the impact of uncontrollable factors, the entire impact is unwound. The approach is conducive for environments similar to those observed for the Corridor 


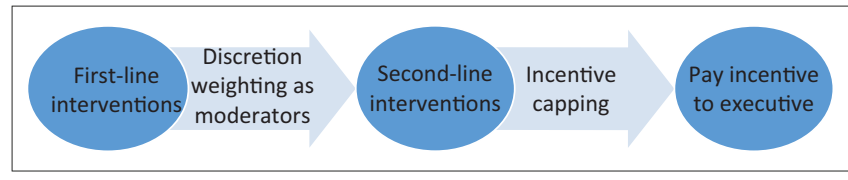

FIGURE 5: Secondary uncontrollable factor interventions.

approach, but it would seem that each organisation decides the extent of application. In an STI scheme for a company in the mining industry, the effects of exchange rates and currencies were deemed by the organisation to be exogenous.

Hybrid approach is a combined application of some of the three approaches mentioned above. In this research, the hybrid approach combinations noted were (1) Hands-off + Corridor and (2) Hands-off + Unwinding, although the researcher could not see any limitation to any other combination given the right context.

\section{Secondary uncontrollable factor approaches}

Profits reflect the sum total of a multiple number of factors working together in the environment that the business operates in. The Rand value of the incentives paid out to executives is of concern to many stakeholders. Secondary interventions are those deployed to address the resultant output of the collective incentive process.

The interventions identified through the research and described below are depicted in Figure 5.

First-line interventions entail the exercise of discretion and the use of weightings as moderators.

Discretion refers to the intervention of a RemCo in response to a unique situation. The discretionary interventions encountered included once-off ex gratia payments and retention payments clearly aimed at purging the exit of talent on account of the impact of an uncontrollable factor on the calculated incentive to be paid. From the executive's view, a Rand is a Rand by any another name, all other things being equal. Respondent 6 successfully sought the intervention of RemCo after his company posted the second highest profit, yet marginally missed its incentives target:

'So I did go to RemCo, I did plead that we were very close to the target and that some consideration should be given for the fact that we got so close to the target. The target was a very big target, so it was close to 400 million. So the shareholders got practically everything they had expected, but management was going to get nothing. So I argued that we should at least get the minimum hurdle for achieving the target. That was the first thing I argued, and then I also argued for another discretionary to lift us above that, on the basis that we had made so much money.' (Respondent 6, CEO, sugar industry)

Weightings as moderators: Conceptually, the use of these should be mutually exclusive to a primary intervention of a specific uncontrollable factor. In Respondent 5's entity, a slump in a commodity price eroded company earnings by $15 \%$. The response of the RemCo was to reduce by more than half the weighting of the commodity impact, effectively reducing the negative exposure of executive incentives to the poor financial results. At a primary intervention level, the company did not adjust for movements in the price of the commodity, therefore practicing the hands-off approach. If they had adjusted at the primary level, then a weighting moderation would not have been necessary or justifiable.

Second-line interventions entail the imposition of caps to limit the incentives paid to executives. By capping the incentive awards, an attempt is being made to address the general concern of excessive executive remuneration, which, as discussed, can in part be attributed to the impact of favourable uncontrollable factors. While capping was widely applied, it does have its disadvantages. Respondent 5 generally showed an adverse attitude to capping, describing what may be termed as a risk of complacent behaviour developing with executives as a result of capping. The respondent felt that management were likely to reduce effort once a capped target had been achieved. In contrast, Respondent 10 asserted:

'But there comes a point where the shareholders' rewards should be more than the CEO's reward ... So an executive incentive scheme, in general, has a zero bottom sometimes, sometimes it's not zero, but it's never negative. Show me an incentive scheme you've found, where if a company loses money, is in the red, and is having to look for funding, that the incentive scheme calls for executives to put in? ... So if there is a cap on the bottom which let's say is zero, why isn't there a cap at the top? ... And if the executive says but why can't I have an unlimited upside, then those building the incentive schemes should say, then you should have an unlimited downside.' (Respondent 10, CEO, executive search agency)

This is a compelling argument, and perhaps, one that might have been expressed more frequently had the sample contained more non-executive shareholders.

\section{Reinforcing activities}

A number of respondents alluded to the importance of organisations not just focusing on the design of schemes but also focusing on how the input of stakeholders is sought and how stakeholders are informed about the remuneration policies of the organisation. The argument, therefore, is that the journey to the point of fairness can be enhanced through dialogue and communication. Fairness is enhanced by understanding, and understanding is conveyed through engagement and transparent disclosure.

Respondents revealed that engagement thrives when it is supported by (1) proactiveness - seeking feedback from the shareholders; (2) delivery - timeously addressing the concerns raised by the stakeholders; and (3) critical mass reaching a large portion of the organisation's stakeholders with an interest in remuneration.

Transparent disclosure speaks to the full conveyance of the remuneration practices within the company to a greater 
audience through best practice. Contributing respondents argue that disclosing policy and the decisions that a remuneration committee might have taken during a period contribute to a better remuneration environment.

\section{A model for uncontrollable factors}

Based on the findings of this research, a model for accounting for uncontrollable factors in executive incentive scheme designs is presented in Figure 6. The model shows stakeholder interests in the executive remuneration domain as an overarching context. The floor of the model shows the enabling activities titled 'stakeholder engagement' and 'transparent disclosure'. Between these two are three chronological levels of actions available to designers of incentive schemes.

\section{Discussion}

This study sought to determine the approaches organisations take and the reasons thereof to account for uncontrollable factors in the design of their executive incentive schemes.

\section{Outline of the results}

The main finding of this research is that South African organisations are not strictly conforming to the classic agency theory prediction for uncontrollable factors as some allow the impact of uncontrollable factors to be included. This finding is consistent with the findings of Deloitte's (2015) quantitative survey of the reaction of US organisations to significant exchange rate movements when it comes to their incentive schemes. The research findings further indicate that some organisations adopt hybrid approaches as opposed to a single approach. The primary driver for this departure from theory is that organisations advocate for recognition that, in as much as a factor is uncontrollable, an agent may have the opportunity to react to the event either as a strategy to mitigate the risk or to cease the opportunity and maximise returns. This finding is consistent with the research work of Mollerstrom et al. (2015), who found that the spectators used in their experimental research, representing principals in the context of this research, were more concerned with the choices made by the agent rather than the cause. If agents can exercise currency hedging, the principal may deem it appropriate to allow for currency impacts to flow through to incentive schemes.

At the heart of the discussion above is the dilemma between agent and principal in relation to paying for individual and organisation linked performance in an environment of uncontrollable factors. Figure 7 captures this dilemma, starting with the financial performance of the organisation as influenced by uncontrollable factors being either good or bad. The individual performance of the executive is then introduced, with two possible outcomes under each firm performance outcome. Next, the strength of the link of executive incentive pay to firm performance, as defined by the design of the performance management system, is introduced, with the strength assigned as high or low. The factors above predict an expected incentive payment which is either high or low. The principal and agent will react to this amount, giving consideration to the circumstances, reflecting either congruence or divergence in sentiments because of the derived incentive award.

\section{Practical implications}

The types of uncontrollable factors at play in the South African environment were identified, and in-depth context was provided exposing a pool of valuable knowledge many other organisations will now have access to as they grapple with how to deal with the uncontrollable factors affecting their operations. The approaches or interventions being used by the different organisations offer a menu that will aid designers of incentive schemes to identify tried and tested approaches to inform their incentive-related policies. While the majority of approach offerings violate the default agency position regarding uncontrollable factors, the acceptance of these approaches by some principals and agents points to the need to update the literature, and for organisations and regulators such as the King Committee, to reconsider longestablished views or positions. In South Africa, proponents who argue for the exclusion of uncontrollable factors from executive remuneration would be supported by the King recommendations, while those in the opposing ranks would have the burden of convincing the other party otherwise. This study reveals that when uncontrollable factors are critically analysed, alternative and possibly more appropriate and fairer views may be formed with the mutual consensus of all interested stakeholders.

The South African forerunner organisations of stakeholder engagement and disclosure regarding executive remuneration, as described in this research, have reported improved climates concerning executive remuneration. By being proactive in stakeholder engagement, aiming to reach a critical mass of stakeholders and timeously addressing issues raised by stakeholders, lagging organisations that follow suit will likely experience the same gains.

\section{Limitations and recommendations}

All research is prone to limitations. The findings derived from the small sample size made up of organisations cannot be extrapolated to, for example, private sector organisations, as the shareholder and executive relationship is likely to have a different context.

\section{Conclusion}

The results of the research identified three broad themes of uncontrollable factors faced by South African companies: (1) Pervasive uncontrollable factors; (2) Industry-specific uncontrollable factors; and (3) Organisation-specific uncontrollable factors.

The findings of the research suggest that South African organisations are not strictly conforming to the classic 


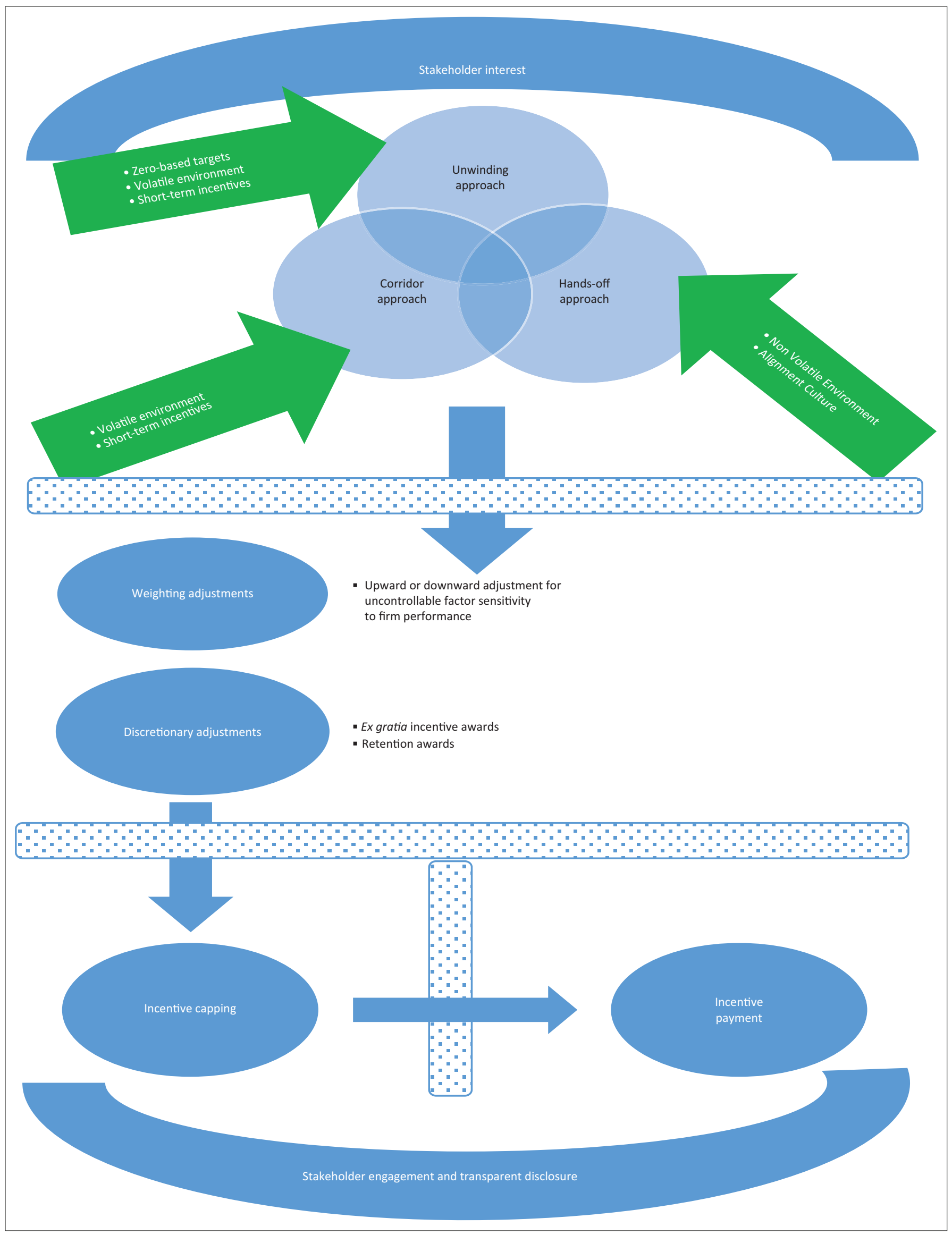

FIGURE 6: A model to account for uncontrollable factors in incentive schemes. 


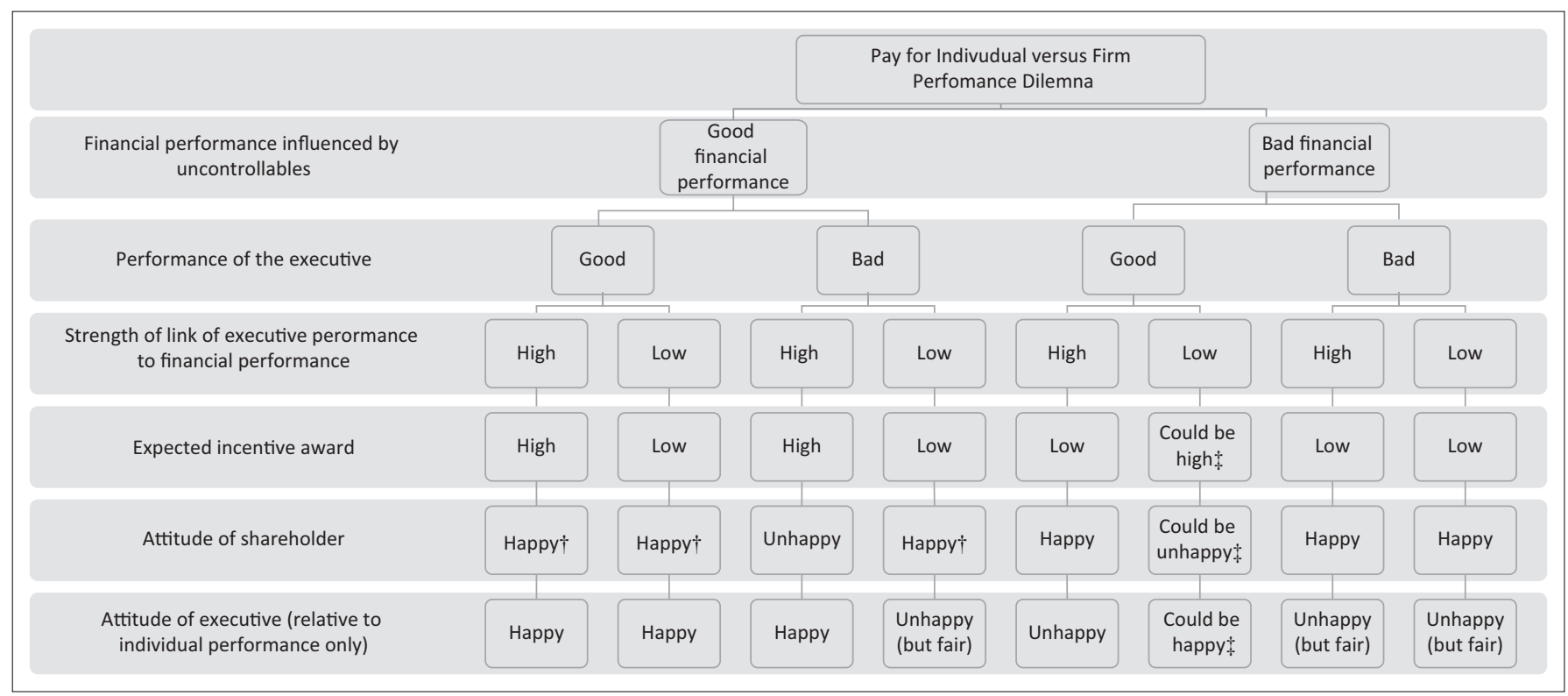

$\dagger$, Assumes shareholder concerns around uncontrollable factors have been addressed through appropriate mechanisms, for example, capping.

* Outcome depends on the mechanics of the non-financial performance-linked targets.

FIGURE 7: The pay for individual versus firm performance dilemma.

agency theory prediction that uncontrollable factors are excluded from incentive remuneration. Some organisations remove the impact of uncontrollable factors in line with classic agency theory prediction for uncontrollable factors. Others depart from classic theory by allowing the impact of uncontrollable factors to be included either entirely or proportionally. Further, hybrid approaches are also applied. These approaches were seen to be front line or primary mechanisms that organisations adopted. The primary driver for those organisations that choose to depart from classic theory is that organisations recognise the choice of the agent rather than the cause of the outcome which classic theory supports.

The impact of uncontrollable factors on executive incentive pay raises concerns for both principal and agent. These concerns are rooted in the dilemma between agent and principal in relation to paying for individual and organisation linked performance in an environment of uncontrollable factors. How an uncontrollable factor is dealt with affects the attitude of both principal and agent. This then brought to the fore secondary mechanisms that organisations adopted. A recurrent finding was that the negative impact of uncontrollable factors increases the flight risk of executives. Consequently, 'rent' payments in the form of ex gratia awards or retention payments to executives are commonly awarded by organisations. On the other hand, the positive impact of uncontrollable factors is seen to induce principals to impose limiting mechanisms such as incentive ceilings.

Worthy of mention are softer practices proactively followed by some organisations to improve the executive remuneration climate. Active stakeholder engagement and executive remuneration disclosures are catalysts to a better executive remuneration environment.

\section{Acknowledgements Competing interests}

The authors declare that they have no financial or personal relationships that may have inappropriately influenced them in writing this article.

\section{Authors' contributions}

The study was conducted by D.V.D. as part of his Master's in Business Administration research project in 2017. M.H.R.B. was D.V.D.'s supervisor and edited the work for publication.

\section{Funding information}

This research received no specific grant from any funding agency in the public, commercial or not-for-profit sectors.

\section{Data availability statement}

Data sharing is not applicable to this article as no new data were created or analysed in this study.

\section{Disclaimer}

The views expressed in this article are those of the researcher and not an official position of any institution.

\section{References}

Bebchuk, L. A., \& Fried, J. M. (2004). Improving executive compensation. In Pay without performance: The unfulfilled promise of executive compensation (pp. 1-9). Havard University Press. Retrieved from http://eprints.cdlib.org/uc/ item $/ 4499 \mathrm{k} 9 w q \% 5$ CnAbstract.

Bebchuk, L. A., \& Fried, J. M. (2006). Pay without performance: Overview of the issues. Academy of Management Perspectives, 20, 5-24. https://doi.org/10.5465/ AMP.2006.19873407.

Bebchuk, L. A., Fried, J. M., \& Walker, D. I. (2002). Managerial power and rent extraction in the design of executive compensation. University of Chicago Law Review, 69(3), 751-846. Retrieved from http://chicagounbound.uchicago.edu/ $\mathrm{cgi} /$ viewcontent.cgi?article $=5183 \&$ context $=u$ clrev. 
Bertrand, M., \& Mullainathan, S. (2001). Are CEOs rewarded for luck? The ones without principals are. The Quarterly Journal of Economics, 116(3), 901-932. without principals are. The Quarterly Journol
https://doi.org/10.1162/00335530152466269

Bezuidenhout, M. L., Bussin, M. H. R., \& Coetzee, M. (2018). The chief executive officer pay - Performance relationship within South African state-owned entities. SA Journal of Human Resource Management, 16, 1-13. https://doi.org/10.4102/ sajhrm.v16i0.983

Blaikie, N. (2011). Interpretivism. In A. Bryman \& T. F. Liao (Eds.), The SAGE encyclopedia of social science research methods (pp. 509-510). Thousand Oaks, CA: Sage. https://doi.org/10.4135/9781412950589

Bol, J. C. (2008). Subjectivity in compensation contracting. Journal of Accounting Literature, 27(1), 1-24. Retrieved from http://papers.ssrn.com/sol3/papers. cfm?abstract_id $=771565$.

Boyce, C., \& Neale, P. (2006). Conducting in-depth interviews: A guide for designing and conducting in-depth interviews for evaluation input. Watertown, MA: Pathfinder International. Retrieved from http://dmeforpeace.org/sites/default/ files/Boyce_In Depth Interviews.pdf.

Brookman, J. T., \& Thistle, P. D. (2013). Managerial compensation: Luck, skill or labor markets? Journal of Corporate Finance, 21(1), 252-268. https://doi.org/10.1016/j. jcorpfin.2013.03.001

Bussin, M. H. R., \& Modau, M. F. (2015). The relationship between Chief Executive Officer remuneration and financial performance in South Africa between 2006 and 2012. SA Journal of Human Resource Management, 13(1), 1-18. https://doi. org/10.4102/sajhrm.v13i1.668

Bussin, M. H. R., \& Ncube, M. (2017). Chief executive officer and chief financial office compensation relationship to company performance in state-owned entities. South African Journal of Economic and Management Sciences, 20(1), 1-10. https://doi.org/10.4102/sajems.v20i1.1644

Campbell, C. T., \& Thompson, M. E. (2015). Why are CEOs paid for good luck? An empirical comparison of explanations for pay-for-luck asymmetry. Journal of Corporate Finance, 35, 247-264. https://doi.org/10.1016/j.jcorpfin.2015.09.006

Cărăușu, D.-N. (2015). Monitor and control in companies: An agency theory approach. Journal of Public Administration, Finance and Law, 2, 46-60. Retrieved from http://web.b.ebscohost.com.uplib.idm.oclc.org/ehost/pdfviewer/ pdfviewer?vid=5\&sid=943f5bb4-ec3f-4233-9da9-a70a977c5b6e\%40sessionmgr102.

Chiu, H. H., Oxelheim, L., Wihlborg, C., \& Zhang, J. (2016). Macroeconomic fluctuations as sources of luck in CEO compensation. Journal of Business Ethics, 136(2), 371-384. https://doi.org/10.1007/s10551-014-2520-1

Cook, K. E. (2012). In-depth interview. In L. M. Given (Ed.), The SAGE encyclopedia of qualitative research methods (p. 423). Thousand Oaks, CA: Sage. https://doi. org/10.4135/9781412963909

Creswell, J. W. (2009). The selection of a research approach. In V. Knight, S. Connelly, \& M. Power Scott (Eds.), Research design: Qualitative, quantitative, and mixed methods approaches (3rd edn., pp. 3-22). Sage. Retrieved from https:// us.sagepub.com/sites/default/files/upm-binaries/55588_Chapter_1_Sample Creswell_Research_Design_4e.pdf.

Crotty, A. (2015). Shareholders revolt over exec cheques at AGMs. Retrieved from http://www.timeslive.co.za/sundaytimes/businesstimes/2015/05/31/Shareholdersrevolt-over-exec-cheques-at-AGMs.

D'Apolito, E., \& lannuzzi, A. P. (2017). Incentive plans, pay-for-non-financial performance and ESG criteria: Evidence from the European banking sector International Business Research, 10(10), 169-181. https://doi.org/10.5539/ibr v10n10p169

Deloitte. (2015). Should FX swings affect incentive compensation? Deloitte CFO Insights. Deloitte. Retrieved from https://www2.deloitte.com/content/dam/ Deloitte/us/Documents/finance/us-cfo-fx-affect-incentive-compensation.pdf.

Donaldson, T., \& Preston, L. E. (1995). Stakeholder theory: Concepts, evidence, corporations and its implications. Academy of Management, 20(1), 65-91. https://doi.org/10.2307/258887

Eisenhardt, K. M. (1989). Agency theory: An assessment and review. Academy of Management Review, 14(1), 57-74. https://doi.org/10.5465/AMR.1989.4279003

Feriozzi, F. (2011). Paying for observable luck. RAND Journal of Economics, 42(2), 387-415. https://doi.org/10.1111/j.1756-2171.2011.00138.x

Ford, J. D. (1985). The effects of causal attributions on decision makers' responses to performance downturns. The Academy of Management Review, 10(4), 770 https://doi.org/10.1109/ACC.2015.7172209

Francis, B., Hasan, I., John, K., \& Sharma, Z. (2013). Asymmetric benchmarking of pay in firms. Journal of Corporate Finance, 23, 39-53. https://doi.org/10.1016/j. jcorpfin.2013.07.004
Freeman, R. E. (1984). Strategic management: A stakeholder approach. Boston, MA: Pitman.

Garvey, G. T., \& Milbourn, T. T. (2006). Asymmetric benchmarking in compensation: Executives are rewarded for good luck but not penalized for bad. Journal of Financial Economics, 82, 197-225. https://doi.org/10.1016/j.fineco.2004.01.006

Gillan, S. L., \& Starks, L. T. (2007). The evolution of shareholder activism in the United States. Journal of Applied Corporate Finance, 19(1), 55-73. https://doi. org/10.1007/978-1-4614-9173-6

Greve, N. (2014). Study finds shareholder activism on the rise. Retrieved from http:// www.engineeringnews.co.za/article/study-finds-shareholder-activism-on-therise-2014-04-22/rep_id:4136.

Hölmstrom, B. (1982). Moral hazard in teams. Bell Journal of Economics, 13(2), 324-340. https://doi.org/10.2307/3003457

Institute of Directors in Southern Africa. (2009). King code of governance principles (King III). https://doi.org/10.1177/1524839909332800

Institute of Directors in Southern Africa. (2016). King IV report on corporate governance for South Africa 2016. Retrieved from http://www.iodsa.co.za/ resource/collection/684B68A7-B768-465C-8214-E3A007F15A5A/IoDSA King IV_Report_-_WebVersion.pdf.

Institute of Directors in Southern Africa. (2017). Fair and responsible remuneration. Remuneration Committee Forum. Retrieved from http://www.ey.com/ Publication/vwLUAssets/ey-iodsa-position-paper-6-march-2017/\$FILE/ey-iodsaposition-paper-6-march-2017.pdf.

Jensen, D. (2008a). Dependability. In L. M. Given (Ed.), The SAGE encyclopedia of qualitative research methods (pp. 100-101). Thousand Oaks, CA: Sage. https:// doi.org/10.4135/9781412963909

Jensen, D. (2008b). Transferability. In L. M. Given (Ed.), The SAGE encyclopedia of qualitative research methods, pp. 886-887. Thousand Oaks, CA: Sage. https://doi. org/10.4135/9781412963909

Jiménez-Angueira, C. E., \& Stuart, N. V. (2013). Relative performance evaluation, pay-for-luck, and double-dipping in CEO compensation. Review of Quantitative Finance and Accounting, 44(4), 701-732. https://doi.org/10.1007/s11156-0130423-3

Jouber, H., \& Fakhfakh, H. (2012). Pay for luck: New evidences from the institutional determinants of CEOs' compensation. International Journal of Law and Management, 54(6), 485-507. https://doi.org/10.1108/17542431211281963

Lincoln, Y. S. (2004). Trustworthiness criteria. In M. B, Lewis-Beck, A. Bryman, \& T. F. Liao (Eds.), The Sage encyclopedia of social science research methods (Vol. 1, pp. 1145-1146). Thousand Oaks, CA: Sage. https://doi.org/10.4135/ 9781412950589

Lu, W., \& Melin, A. (2016). The best (and worst) countries to be a woman. Retrieved from https://www.bloomberg.com/news/articles/2016-11-16/ranking-where-towork-to-be-a-rich-ceo-or-richer-than-neighbors.

Mollerstrom, J., Reme, B. A., \& Sørensen, E. T. (2015). Luck, choice and responsibility An experimental study of fairness views. Journal of Public Economics, 131, 33-40. https://doi.org/10.1016/j.jpubeco.2015.08.010

Morgan, D. L. (2012). Sample size. In L. M. Given (Ed.), The SAGE encyclopedia of qualitative research methods (pp. 798-799). Thousand Oaks, CA: Sage. https:// doi.org/10.4135/9781412963909

Paulo, S., \& Le Roux, P. (2016). The 'pay ratio' provision of the Dodd-Frank Act 2010 and presentation of the Paulo-Le Roux Index. SA Journal of Human Resource Management, 14(1), 1-11. https://doi.org/10.4102/sajhrm.v14i1.803

Pope, C., Ziebland, S., \& Mays, N. (2000). Analysing qualitative data. British Medical Journal, 320(7227), 114. Retrieved from http://search.ebscohost.com/login.aspx? direct=true $\& d b=a 9 h \& A N=2704775 \&$ site=ehost-live $\&$ scope=site

Saunders, M. N. K., \& Lewis, P. (2012). Doing research in business \& management Harlow: Pearson Higher Ed.

Seale, C. (2004). Replication/replicability in qualitative research. In M. S. Lewisbeck, A. Bryman, \& T. F. Liao (Eds.), The SAGE encyclopedia of social science research methods (pp. 962-963). Thousand Oaks, CA: Sage. https://doi.org/ 10.4135/9781412950589

Securities and Exchange Commission. (2015). Proposed rule: Pay versus performance USA: Securities and Exchange Commission. Retrieved from https://www.sec.gov/ rules/proposed/2015/34-74835.pdf.

Sun, Y., \& Shin, T. (2014). Rewarding poor performance: Why do boards of directors increase new options in response to CEO underwater options? Corporate increase new options in response to CEO underwater options? Corporate corg.12065 